\title{
Experience with Social Distancing Early in the COVID-19 Pandemic in the United States: Implications for Public Health Messaging
}

Ryan C. Moore ${ }^{1}$, Angela Lee ${ }^{1}$, Jeffrey T. Hancock PhD', Meghan Halley PhD ${ }^{3}$, Eleni Linos, MD, $\mathrm{DrPH}^{2,3}$

From the Departments of Communication ${ }^{1}$, Dermatology ${ }^{2}$ and Epidemiology ${ }^{3}$, Stanford

University, CA, USA

\section{Correspondence to:}

Eleni Linos, MD, MPH, DrPH

Professor, Departments of Dermatology, Epidemiology and Population Health

Stanford University School of Medicine

269 Campus Drive, Suite 4235 CCSR

Palo Alto, CA 94305 USA

Mail Code 5179

Email: linos@stanford.edu

Keywords: coronavirus, COVID-19, natural language processing, public health messaging, social distancing compliance

Funding: EL (grants DP2CA225433 and K24AR075060) and MH (grant DP2CA225433-02) are supported by the $\mathrm{NIH}$. The content is solely the responsibility of the authors and does not necessarily represent the official views of the $\mathrm{NIH}$. 
medRxiv preprint doi: https://doi.org/10.1101/2020.04.08.20057067; this version posted April 11, 2020. The copyright holder for this preprint (which was not certified by peer review) is the author/funder, who has granted medRxiv a license to display the preprint in perpetuity.

All rights reserved. No reuse allowed without permission.

Our goal is to inform ongoing public health policy on the design and communication of COVID-19 social distancing measures to maximize compliance. We assessed the US public's early experience with the COVID-19 crisis during the period when shelter-in-place orders were widely implemented to understand non-compliance with those orders, sentiment about the crisis, and to compare across age categories associated with different levels of risk. We posted our survey on Twitter, Facebook, and NextDoor on March $14^{\text {th }}$ to March $23^{\text {rd }}$ that included 21 questions including demographics, impact on daily life, actions taken, and difficulties faced. ${ }^{1}$ We analyzed the free-text responses to the impact question using LIWC, a computational natural language processing tool ${ }^{2}$, and performed a thematic content analysis of the reasons people gave for non-compliance with social distancing orders. Stanford University's IRB approved the study.

In 9 days, we collected a total of 20,734 responses. 6,573 individuals provided a response ( $\geq 30$ words) to the question, "Tell us how the coronavirus crisis is impacting your life." Our data (Figure 1) show that younger people (18-31) are more emotionally negative, self-centered, and less concerned with family, while middle-aged people are group-oriented (32-44) and focused on family (32-64) (all $p$ values $<.05$ corrected for multiple comparisons). Unsurprisingly, the oldest and most at-risk group (65+) are more focused on biological terms (e.g., health-related topics), but were surprisingly low in anxiety and high in emotionally positive terms relative to those at lower risk.

We also content-analyzed 7,355 responses (kappa's $>.75$ ) to the question, "What are the reasons you are not self-isolating more?" Of these participants, 39.8\% reported not being compliant, with the youngest group (18-31) having the lowest compliance rate $(52.4 \%)$ compared to the other age groups (all $>60 \%$; all $p$ values $<.01$ ). Table 1 describes the seven

\footnotetext{
${ }^{1}$ Nelson LM, Simard JF, Oluyomi A, et al. US Public Concerns About the COVID-19 Pandemic From Results of a Survey Given via Social Media. JAMA Intern Med. Published online April 07, 2020. doi:10.1001/jamainternmed.2020.1369

${ }^{2}$ Pennebaker, J. W., Boyd, R. L., Jordan, K., \& Blackburn, K. (2015). The development and psychometric properties of LIWC2015. (https://repositories.lib.utexas.edu/bitstream/handle/2152/31333/LIWC2015_LanguageManual.pdf)
} 
medRxiv preprint doi: https://doi.org/10.1101/2020.04.08.20057067; this version posted April 11, 2020. The copyright holder for this preprint (which was not certified by peer review) is the author/funder, who has granted medRxiv a license to display the preprint in perpetuity. All rights reserved. No reuse allowed without permission.

primary themes for non-compliance. Non-essential work requirements, concerns about mental and physical health, and the belief that other precautions were sufficient were the most common reasons, although other rationales included wanting to continue everyday activities and beliefs that society is over-reacting. Childcare was an important concern for a subset of respondents.

Overall, our findings suggest that public health messages should focus on young people and 1) address their negative affect, 2) refocus their self-orientation by emphasizing the importance of individual behavior to group-level health outcomes, and 3) target the specific rationales that different people have regarding the pandemic to maximize compliance with social distancing. 
medRxiv preprint doi: https://doi.org/10.1101/2020.04.08.20057067; this version posted April 11, 2020. The copyright holder for this preprint (which was not certified by peer review) is the author/funder, who has granted medRxiv a license to display the preprint in perpetuity.

All rights reserved. No reuse allowed without permission.

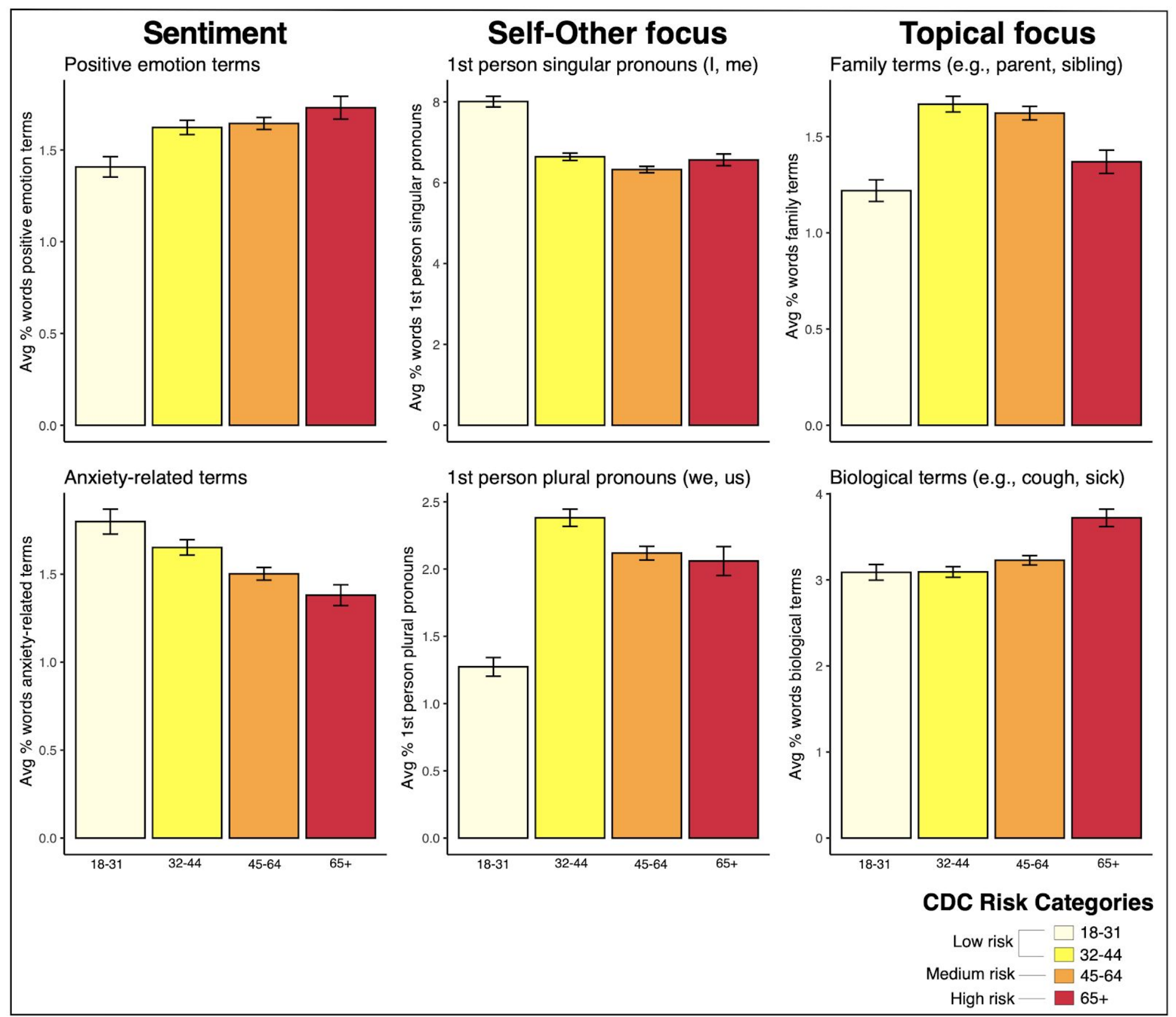

Figure 1. Mean number of words in language categories, by age group. Age groups are modeled after the age groups reported by the Center for Disease Control in their summary of COVID-19 cases in the US. ${ }^{3}$ Bars represent standard errors.

${ }^{3}$ Severe Outcomes Among Patients with Coronavirus Disease 2019 (COVID-19) — United States, February 12-March 16, 2020 (https://www.cdc.gov/mmwr/volumes/69/wr/mm6912e2.htm) 
medRxiv preprint doi: https://doi.org/10.1101/2020.04.08.20057067; this version posted April 11, 2020. The copyright holder for this preprint

(which was not certified by peer review) is the author/funder, who has granted medRxiv a license to display the preprint in perpetuity.

All rights reserved. No reuse allowed without permission.

Table 1. Primary Themes for Non-Compliance and Messaging Strategies

\begin{tabular}{|c|c|c|c|}
\hline Theme & Example & $\%$ Freq & $\begin{array}{l}\text { Messaging Strategy to } \\
\text { Increase Compliance }\end{array}$ \\
\hline $\begin{array}{l}\text { Non-Essential } \\
\text { Work }\end{array}$ & $\begin{array}{l}\text { "Work is not canceled, if I don't go } \\
\text { I'll lose my job." }\end{array}$ & 28.2 & $\begin{array}{l}\text { Convey forthcoming } \\
\text { government support; } \\
\text { Communicate necessity of } \\
\text { remote work solutions to } \\
\text { employers }\end{array}$ \\
\hline $\begin{array}{l}\text { Mental \& Physical } \\
\text { Health }\end{array}$ & $\begin{array}{l}\text { "Total self isolation would probably } \\
\text { drive me to suicide." }\end{array}$ & 20.3 & $\begin{array}{l}\text { Recognize hardships, } \\
\text { identify safe well-being } \\
\text { activities }\end{array}$ \\
\hline $\begin{array}{l}\text { Taking Sufficient } \\
\text { Precautions }\end{array}$ & $\begin{array}{l}\text { "I already wash my hands regularly } \\
\text { and cover my mouth when I cough } \\
\text { or sneeze. I am not concerned with } \\
\text { catching [the] virus." }\end{array}$ & 18.8 & $\begin{array}{l}\text { Explain why stronger } \\
\text { measures required; Convey } \\
\text { norms about compliance }\end{array}$ \\
\hline $\begin{array}{l}\text { Non-Essential } \\
\text { Activities }\end{array}$ & $\begin{array}{l}\text { "Some appointments are in-person. } \\
\text { Need to see friends sometimes." }\end{array}$ & 13.9 & $\begin{array}{l}\text { Provide clarity on what } \\
\text { activities are essential }\end{array}$ \\
\hline $\begin{array}{l}\text { Society } \\
\text { Over-Reacting }\end{array}$ & $\begin{array}{l}\text { "I think the news media was making } \\
\text { everyone panic and overreact." }\end{array}$ & 12.7 & $\begin{array}{l}\text { Emphasize danger to all if } \\
\text { society is compromised }\end{array}$ \\
\hline Childcare-Related & $\begin{array}{l}\text { "Really really hard to do with little } \\
\text { kids - I'm reducing a lot of contact, } \\
\text { but not all." }\end{array}$ & 4.8 & $\begin{array}{l}\text { Construct parent-specific } \\
\text { recommendations }\end{array}$ \\
\hline $\begin{array}{l}\text { Government- } \\
\text { Related }\end{array}$ & $\begin{array}{l}\text { "There has been a lack of clear } \\
\text { direction on when one should start } \\
\text { to seriously isolate." }\end{array}$ & 1.4 & $\begin{array}{l}\text { Develop consistent } \\
\text { messaging from federal, } \\
\text { state and local levels of } \\
\text { government }\end{array}$ \\
\hline
\end{tabular}

Acknowledgements: We would like to acknowledge the individuals who helped with the survey dissemination online. 